\title{
Spiritual Inheritance: A Case Study of Henan Opera
}

\author{
Xiao Wang* \\ Academic Affairs Office, Minzu University of China, Beijing 100091, China \\ *Corresponding author: Xiao Wang, XiaoWang-EM@ hotmail.com
}

\begin{abstract}
Despite many scholarly debates on Chinese opera, the study of how opera hit rock bottom remains scarce. Therefore, this article addresses this reason through a case study of Henan Opera. Informed by a systematic approach, there have been various improvements, good and bad criticisms, as well as affirmations in regard to opera. The lack of the Chinese opera spirit is the root of the difficulties in the development of Chinese opera.
\end{abstract}

Keywords: Chinese opera; Henan opera; Spiritual inheritance; Systematic approach

Publication date: September 2021; Online publication: September 30, 2021

\section{Introduction}

Henan Opera, also known as Henan bangzi, alongside Beijing Opera, Huangmei Opera, Yue Opera,aAnd Ping Opera are the five major operas ${ }^{[1,2]}$. They are the country's first batch of intangible cultural heritage. There are more than 2000 private theatrical troupes in Henan area, its surrounding areas, Xinjiang, and Taiwan. There are four major types of Henan Opera: Eastern Henan tune, West Henan tune, Shahe tune, and Xiang-fu tune. Since Fan Cuiting joined the Henan Opera Reform Movement in 1934, the promotion of Chang Xiangyu, the rise of the modern Henan Opera Chaoyang Ditch, and the market-oriented reform of the Little Queen Troupe as an independent drama troupe, Henan Opera has been developing forward ${ }^{[3]}$. Its singing is infectious, full of passion, emotions, and local flavor, displaying the emotional characteristics and spiritual outlook of Henan people. Through the study of music, the source of Henan opera in the past mainly came from the farmers, in which the teaching is from generation to generation. However, after the founding of New China, the actors are mainly from drama schools. They do not have high cultural level, but through years of intensive training, they mastered the art of singing ${ }^{[4,5]}$.

\section{Origin of Henan Opera in the late Ming and early Qing Dynasties}

There are many opinions in regard to the origin of Henan Opera. Some believe that it originated from the "The music of the states of Zheng and Wei," while others believe that it originated from the foreign Qin Opera in combination with local tunes. Ever more so, there are scholars who believe that Henan Opera originated from farmers who worked in fields, having art performances in the form of singing and dancing. However, compared with the performing arts of Peking Opera, there is no gorgeous language or exquisite singing. Henan Opera is called "Tu Opera" by many locals. This shows that Henan Opera is derived from the folk, having a connection with local civilization. At the end of Ming Dynasty and the beginning of Qing Dynasty, the ruling class focused on recuperation, reducing taxes, and agricultural development. The opera in Henan region has achieved unprecedented development. The main reason is that Henan Opera is grounded, mainly involves singing, as well as easy to understand and accept. In addition, the large-scale lyrics have been integrated with common sayings and slangs from the Henan region. The content of the 
opera changed along with the rumors and deliberations of the court, and is satisfied with the curiosity of the vast number of peasants. The content usually includes the three cardinal guides and five constant virtues as well as loyal and filial piety, which are in line with the spiritual demands of the ruling class and the majority of farmers. In the early days of the Henan Opera, foreign dramas were widely absorbed and integrated in it. Although it looked rough, it was pleasant to hear and it was the word of mouth; thus, the art of Henan Opera was born ${ }^{[6]}$.

\section{Rapid growth of Henan opera during the reign of Jiaqing and Daoguang in the Qing Dynasty}

During the rapid growth of Henan Opera, four major types were formed based on different regions: Xiangfu tone, Shahe tone, Eastern Henan tune, and Western Henan tune. Xiang-fu tone (with Kaifeng as the center), which is the externalization of the simple character of Henan people, is simple but thick and euphemistic but implicit. East Henan tune (with Shangqiu as the center) is passionate. It is the externalization of the diligence and forthright character of the people in Henan. The Western Henan tune (with Luoyang as the center) is the externalization of the compassionate emotion of the people in Henan for the earth and heaven. Shahe tune (with Shahe River Basin as the center), being lively and clever, is the externalization of the personality of the people in Henan, assimilating both Chinese and foreign personalities, which are flexible, changing, and forthright transparent. In these ways, Henan Opera expressed the Henan people's pursuit. Although the four major tunes are quite different, they are in fact the same essentially. In the aesthetic field, no matter how the stage is set or the singing characteristics, it is in line with the aesthetic needs of the people in Henan, which in turn further affects the aesthetic values of the Chinese.

In regard to beliefs, people naturally do not wish to harm others, and in the same way, they do not want to be infringed by other people also. This natural belief melts in the hearts of the nation and guides people in their thinking and actions. In the construction of this belief, Henan Opera itself plays a role in the repertoire performance.

At the ideal level, although the Chinese people do not believe in Jesus, there is a saint, Kong-zi, who is the role model and spiritual leader in the minds of the Chinese people.

Firstly, Henan Opera has become a fixed performing group in the rapid development stage. It is relatively fixed and complex. It involves the control of famous actors. A good actor can support a troupe or be the revenue for a troupe. If a drama is in line with socialist value, officials do not usually participate in it, whose power is actually a review mechanism. The cognitive levels of the famous actors in Henan Opera actually determines its lower limit. Therefore, it is necessary to pay attention to the improvement of cultural knowledge among the actors.

Secondly, in the 1920s, Fan Cuiting, who received higher education, joined the opera reform ${ }^{[7]}$. He had an excellent writing style, and he integrated vulgar contents in the scripts. In addition to that, the Yusheng Theatre was also established, which improved the ideological level of Henan Opera and promoted the urbanization establishment of this opera. The audience of the theater, from farmers, small merchants, and hawkers, worked hard, and eventually the people of the opera became members of the upper class. However, the Henan Opera is still inextricably linked to the lives of the audience. Fan Cuiting's improvement of the script has laid the cultural heritage and humanistic feelings of Henan Opera and has made it free from vulgarity. During that time, the ideological nature of its scripts made great progress, where the ideologies of male superiority, ignorance, and backward feudalism have been abolished. In turn, they expressed patriotism with distinctive nationality and moral enlightenment. All these actively brought positive energy to the society in line with the expectations and the demands of the times. 


\section{Chang Xiangyu was the main focus on the re-improvement of the opera at the founding of People's Republic of China}

In the early days of the establishment of the People's Republic of China, a large number of outstanding Henan Opera artists flocked to the country, among which Chang Xiangyu was the best, who learned from others and introduced the performing arts of Peking Opera to Henan Opera. In order to further improve the aesthetic appeal of Henan opera, Chang Xiangyu, as one of the four famous performers, responded to the call of the party and the state to rearrange and rehearse the traditional opera repertoire in combination with the social environment of the new era, redefine the meaning of opera, as well as optimize the singing aspect of the opera; they are all named based on the different regions in Henan. Nowadays, the art of opera has more prominent individualized characteristics and has gradually established various new genres such as "Changpai." The growth of Henan Opera led to new developments and characteristics but there is no change to the spiritual core of the opera; in fact, it integrates people's love for freedom and peace, resistance to oppression, sincerity and kindness of the times, as well as their spirit ${ }^{[8]}$.

\section{Domination of private troupes by the Little Queen Henan Opera Troupe after the reform and opening-up}

With the reform and opening-up, the state's literature and art policies have been continuously modified, depicting a state of "let a hundred flowers bloom and a hundred schools of thought contend," to encourage more art-skilled groups to actively participate. The Little Queen Henan Opera Troupe, as a private opera troupe, has a lighter burden and is more flexible in adjusting its performances and performance environment. It took root in rural areas and performed more than 6,000 performances with as many as 30 million audiences. The troupe was involved deeply in the grassroots frontline and insisted on bringing their performances to the countryside. A good harvest of economic and social benefits has been achieved through this. At the spiritual level, Wang Hongli did not only advocate the promotion of traditional social values but also took into consideration of core socialist values of the new era and respected the laws of the market. It has won wide acclaim in the fierce social competition.

\section{The brilliance of Henan opera brought about by the Pear Garden Spring}

In the year of 2000, due to the emergence of new audio-visual methods, televisions began to be a part of thousands of households. As Henan Television's trump card program, "Li Yuan Chun" has achieved the ultimate in the segmented program field, and the audience behind it has been praised by ordinary amateurs

${ }^{[9]}$. In this program, experts would evaluate an individual's charm on stage. There are even various economic and cultural incentives, such as lucky draws, which fully mobilize the enthusiasm of people to participate in Henan Opera. Henan Opera has become popular in Henan, where many parents would send their children to be participants, thus further promoting the development of Henan Opera. The excerpts of Henan Opera are mostly well-known classic songs with high popularity. The classic songs have distinctive vocals, full of affection, and rich meaning. They integrate traditional etiquette and moral education. In addition, the masses have shown a new breath in the new era, which not only embodies the requirements of the development of the times, but also inherits the essence of traditional culture.

\section{Impact of the diversification of entertainment media}

As of April 26, 2021, through the Web of Science database, there were only a few articles on Henan Opera by foreign scholars. Most research were written or published by Chinese people, mainly focusing on Henan universities, research institutes, theatrical troupes, and competition agencies. In view of the number of graduate students (master's and doctorate) over the years according to the National Bureau of Statistics, art 
graduates ranked $10^{\text {th }}$ in the subject category, specifically in music while for science and engineering, the number is still very small.

Even in today's cultural education, although the cultivation of cultural literacy and knowledge structure is emphasized, music and other arts pay no more attention to it. In the Central Plains culture, in line with Han people's forbearance and concession character, the right way of Gold List Title has been highly valued [5].

However, the actors usually have strong practical skills and stage performances, contributed by their creative ability and research ability through theoretical guidance and practice or theoretical summary. According to the statistical analysis of China Central Television audio-visual big data by the State Administration of Radio, Film, and Television, 383 theme programs and 328 weekly variety shows were broadcasted on the channel in 2020. Although variety shows, poetry, music, blind date, and talk shows are included, opera did not enter this list.

As of January 2021, to May 2021, the average attention of Li Yuan Chun (a variety show in Henan) live broadcast was 0.659 and the average market share was 4.082. Among all kinds of plays, Henan Opera has the best living condition but even in this way, the huge gap between the art market and people's needs has led to the irreversible decline of opera.

First, the pace of life has become faster, thus aesthetic habits have changed dramatically. This has been brought difficulty in the enjoyment of slow-paced opera for a long time. Second, the reform of the inherent singing structure has been changed as exemplified by the display of a real boat but not the gesture simulation in the present performance; this does not cater to young people. Finally, despite the emphasis on localization, the opera still heavily relies on traditional performance programs, singing skills, and a set of unique artistic style ${ }^{[6]}$.

Henan Opera is drifting further away from people compared with the well-known "Chaoyang Gou" in the 1950s and the realistic "Unlucky Uncle Lucky in Love." The current ecology in production is about pushing tens of millions to rehearse by the state and winning awards in Beijing. The actors themselves are mentality impetuous, acting in several works, and winning several awards, thus making opera more like an assembly line product and losing its cultural aspect.

The reason for that is because in the past, countrysides have no electricity or convenient tools; thus, people would walk to the temple fair to watch operas. This way of living becomes a platform for farmers to communicate and express their love. However, at present, with the diverse and urbanized ways of living, where movies, dramas, operas, musicals, dance dramas, crosstalk, short sketches, self-media, and mobile phone are in abundance, people have become overwhelmed with the processing of information and choosing their own interests becomes an issue.

Existing art groups have made huge attempts, such as upgrading aesthetic dances, strengthening the reality of scenes, reconstructing scripts, extracting classical lyrics to form fold plays, adding modern elements, as well as having more highly educated actors and actresses that have graduated from drama schools. All these measures show people's misunderstanding of Henan Opera. The changes are superficial; thus, it is impossible to have a deep theoretical level. Moreover, current research have shown that Henan Opera is a cultural attribute that represents the living state of the people in a region, such as in Taiwan, where its localization has become a part of Taiwan Opera. However, many researchers think that the style, rhythm, melody, and track of Henan Opera are too old, and it needs to keep pace with the times, being the core issue [6].

\section{Conclusion}

Henan Opera is called "Henan" because it is the view of life, values, and world outlook of Henan people. Henan Opera comes from the countryside; hence, creators, writers, actors, and accompaniment personnel 
should return to the countryside, similar to what Fan Cuinting did when he created Henan Opera.

Although opera is a musical expression, it is actually a culture. Opera may not be as popular as pop music with idols who have a high income and popularity; instead, it deeply imprints the genes of a generation's cultural memory, which is different from the remarkable characteristics of other regional people, allowing them to have their own cultural belonging.

Perhaps due to urbanization, the audience may not understand its connotation well but in rural civilization, its vitality is vigorous. Using this as the starting point, opera would then be able to find its roots, cultural attributes, and become evergreen.

\section{Disclosure statement}

The author declares that there is no conflict of interest.

\section{References}

[1] Quanyou SU, Liu Z, 2013, Review of the Modern History of Henan Opera Since the Founding of New China. Journal of Zhoukou Normal University, (01): 110-117.

[2] Yang JT, 2010, The Innovation of the Mode of Liyuanchun to Chinese Traditional Opera. Journal of Kaifeng Institute of Education, 30(001): 74-76.

[3] Rao NY, 2018, Inside Chinese Theatre: Cantonese Opera in Canada. Intersections, 38(1-2), 81-104. https://doi.org/10.7202/1071675ar

[4] Wang Q, 2015, Research on Male Dan in Chinese Peking Opera and Castrato in Italian Opera. International Conference on Economics, : 78-82.

[5] Huang W, 2011, "Entertainment" and "Enlightenment": The Dual Role of Henan Local Opera during the Reform in the Republic of China Period. Journal of National Museum of China, (06): 134-141.

[6] Liu M, 2013, The Development Characteristics and Analysis of Dilemma of Henan Opera. Journal of Henan Mechanical and Electrical Engineering College, 000(002): 70-73.

[7] Cheng G, 2017, Expounding the Reform and Practice of Henan Opera by Fan Cuiting. Journal of Lingnan Normal University, (2): 110-115.

[8] Pei DU, 2006, On the Vocal Charm of Chang Xiangyu's Henan Opera Arias. Humanities \& Social Sciences Journal of Hainan University, 024(001): 129-133.

[9] Yang JT, 2010, The Innovation of the Mode of Liyuanchun to Chinese Traditional Opera. Journal of Kaifeng Institute of Education, 30(001): 74-76. 